\title{
Pengoptimalan Sobat Mengajar sebagai Gerakan Sosial Pendidikan dalam Membangun Pendidikan di Daerah Tertinggal
}

\author{
Sihabussalam ${ }^{1}$ \\ ${ }^{1}$ Program Studi Ilmu Al-Quran dan Tafsir, Fakultas Ushuluddin, Universitas Islam Negeri Syarif Hidayatullah \\ Jakarta, Jl. Ir H. Juanda No. 95, Cempaka Putih, Ciputat, Tangerang Selatan, Banten 15412 \\ Penulis untuk Korespondensi/Email: sihabussalam471@gmail.com
}

Abstrak - Pendidikan adalah sebuah proses manusia baik individu atau masyarakat untuk menuju kehidupan yang ideal dan lebih baik. Pendidikan yang akan mengubah menuju ke arah yang lebih baik adalah pendidikan yang kualitasnya baik pula. Tetapi melihat realitas sekarang, kualitas pendidikan di Indonesia masih rendah apalagi dalam hal pemerataan pendidikan, di antaranya: fasilitas, akses, dan tenaga pengajar yang akan berimplikasi pada proses belajar dan hasil belajar, keadaan tersebut salah satunya gambaran pendidikan yang ada di daerah terpencil. Dengan demikian, penelitian ini akan berfokus pada masalah pemerataan pendidikan di daerah terpencil dengan cara mengoptimalkan komunitas sobat mengajar sebagai gerakan sosial pendidikan. Komunitas ini bergerak di daerah-daerah terpencil khususnya di Kabupaten Lebak, Provinsi Banten, kajian awal mencari data keadaan pendidikan di daerah tersebut dengan cara membaca literature dan wawancara langsung kepada relawan sobat mengajar kemudian hasilnya dideskripsikan, dengan demikian penelitian ini menggunakan metode deskriptif kualitatif. Untuk mengatasi tidak meratanya pendidikan di Indonesia ada beberapa langkah yang harus dilakukan: pertama, mengoptimalkan gerakan sosial pendidikan. Kedua, melakukan program yang mengedukasi masyarakat. Ketiga, harus melibatkan masyarakat dalam semua program.

Abstract - Education is a human process, either an individual or a society towards an ideal and better life. Education that will change for the better is education that is of good quality too. But look at the current reality, the quality of education in Indonesia is still low especially in terms of equitable education for example lack of facilities, access, and teaching staff that will have implications for the learning process and learning outcomes, they are one picture of the conditions that exist in remote areas. Therefore, this research will focus on the problem of equitable education in remote areas by optimizing the community of sobat mengajar as a social education movement. This community is moving in remote areas especially in lebak regency, the province of banten, early studies looking into educational conditions in the region, the initial study looked for data on the state of education in the area by reading literature and direct interviews with volunteers of sobat mengajar then the results were described, thus this study using a descriptive qualitative methods. To overcome the unequal education in Indonesia, several steps must be taken: the first, optimize the social education movement. The second is to carry out programs that educate the public. The third is must involve the society in all programs.

Keywords - Sobat mengajar, Educational social movements, Building education, Disadvantaged areas. 


\section{PENDAHULUAN}

$\mathrm{P}^{\mathrm{e}}$ endidikan merupakan sarana atau media agar manusia menjadi khairu ummah "umat paling baik". Dengan kodratnya manusia menjadi khalifah di muka bumi ini akan sangat membutuhkan pendidikan sebagai bekal dalam membentuk dirinya menjadi khalifah yang paripurna. Pada dasarnya, terciptanya kesejahteraan, pemerataan, keadilan, dan keindahan di bumi ini adanya campur tangan manusia sebagai pengelola. Dalam memberi tugas kepada manusia, tentunya Allah membekali manusia itu dengan yang namanya potensi diri. Berbagai macam potensi yang diberikan bertujuan sebagai alat untuk menyelesaikan problematik di bumi dan berusaha memakmurkannya.

Makna yang terkandung dalam memakmurkan adalah adanya kemajuan dan kesinambungan kehidupan di bumi ini. Dalam perspektif sejarah, adanya peradaban baik dunia Islam ataupun Barat salah satunya dengan pendidikan yang berkualitas. Pernyataan tersebut memberikan penegasan bahwa pendidikan yang ideal dan berkualitas akan memberikan pengaruh terhadap kehidupan masyarakat dan memberikan nilai yang lebih terhadap negara. Dengan gambaran tersebut, pemerintah sebagai roda berjalannya sebuah negara harus benar-benar merumuskan sistem pendidikan yang bermutu, menyeluruh, dan berkualitas.

Pendidikan sendiri merupakan hak yang harus didapatkan oleh semua elemen masyarakat meliputi sarana, biaya, sistem yang baik, serta dibangun atas nilai-nilai agama yang menuju kesejahteraan umat manusia. Poin-poin tersebut sebagaimana yang tercantum dalam UUD 1945 pasal 31. Dengan demikian, pendidikan nasional harus memberikan pendidikan dasar kepada masyarakat, kemampuan dasar, meliputi membaca, menulis, dan berhitung yang nantinya akan menjadi dasar bagi warga negara dalam bermasyarakat, berbangsa, dan bernegara.

Pendidikan tersebut tampaknya tidak berjalan dengan baik terlebih mencakup hak bagi seorang warga negara, karena sebagian wilayah Indonesia masih mengalami pendidikan yang tidak layak, seperti sarana, biaya, infrastruktur, yang berdampak pada kualitas pendidikan. Menurut pusat data dan statistik Kemdikbud (Kementerian Pendidikan dan Kebudayaan) 2017-2018, dari seluruh sekolah di Indonesia, 90.749 ruang kelas rusak berat dan 60.749 ruang kelas rusak total. Dari 214.409 sekolah semua jenjang hanya 144.293 sekolah yang memiliki perpustakaan, dari 144.293 perpustakaan, 6.436 perpustakaan mengalami rusak berat dan 5.529 perpustakaan rusak total. Untuk daerah Banten, dari 37.282 ruangan kelas sekolah SD, sebanyak 1.704 mengalami kerusakan berat dan 1.155 mengalami kerusakan total. Sedangkan pada 2018/2019, dari 37.259 sebanyak 2.160 mengalami kerusakan berat. Melihat data tahun ini dan setahun ke belakang di daerah Banten mengalami peningkatan terkait keadaan ruang kelas yang rusak berat [1].

Melihat masih banyaknya masalah pendidikan terutama di daerah tertinggal, hal demikian perlu adanya tindakan sebagai solusi untuk mengurangi kesenjangan pendidikan dan tidak meratanya pendidikan khususnya di daerah Sobang, Banten. Salah satu upaya untuk membantu pemerintah dalam masalah pendidikan, sobat mengajar hadir, sebuah komunitas yang bergerak dalam hal sosial pendidikan. Dalam penelitian ini ada beberapa poin yang menjadi rumusan masalah; pertama, apa itu sobat mengajar? Kedua, bagaimana sosial pendidikan dalam perannya untuk pendidikan daerah tertinggal? Ketiga, bagaimana pendidikan membentuk peradaban dan menuju khairu ummah? Adapun tujuan penelitian ini adalah memperkenalkan sobat mengajar sebagai komunitas sosial pendidikan yang peran dan fungsinya menyelesaikan problem pendidikan di daerah tertinggal dan membangun kualitas pendidikan. Dimulai dengan menyelesaikan masalah pemerataan pendidikan dengan agenda yang kreatif dan inovatif sebagai basis untuk menuju mutu pendidikan yang lebih baik dan pada akhirnya menjadi umat terbaik (khairu ummah).

\section{METODE}

Metode yang digunakan dalam tulisan ini adalah analisis-deskriptif, yaitu dengan menganalisis dan memberikan gambaran terkait dengan masalah untuk memberikan pemahaman yang menyeluruh. Adapun teknik pengumpulan data pada penelitian ini adalah studi pustaka dengan menggunakan referensi baik itu buku, jurnal yang berhubungan dengan masalah tersebut. Dalam pengambilan data terkait studi kasus, masalah, dan keberadaan sobat mengajar maka dilakukan wawancara terhadap salah satu relawan sobat mengajar yang perannya sangat krusial dan menjadi salah satu aktor lahirnya sobat mengajar. 
Metode penelitian ini, menggunakan beberapa langkah. Langkah pertama adalah menentukan objek penelitian, dalam hal ini yaitu masalah tidak meratanya pendidikan terutama di daerah tertinggal, khususnya daerah di Provinsi Banten Kabupaten Lebak. Sebagaimana data dari Kemdikbud bahwa masih rendahnya pendidikan di daerah tersebut, terutama dalam hal fasilitas yang akan berimplikasi pada kualitas pendidikan di daerah tersebut. Setelah mendapatkan data dengan teknik membaca dan wawancara kemudian diidentifikasi, lalu data tersebut dideskripsikan.

Adapun langkah penelitiannya sebagai berikut: pertama, membaca literature dan mengamati situasi pendidikan di Indonesia, kemudian diidentifikasi permasalahan pendidikan yang krusial, setelah mendapatkan hasil, lalu menetapkan satu daerah yang dapat mewakili keadaan pendidikan di Indonesia, dengan demikian penelitian ini bersifat deduktif.

Langkah selanjutnya membaca ulang data-data atau hasil dari langkah pertama guna mendapatkan informasi yang lengkap terkait masalah yang akan diteliti yaitu keadaan pendidikan di daerah tertinggal, kemudian ditulis penemuan atau hasil dari langkah kedua dengan tujuan untuk dianalisis dan dideskripsikan, sekaligus akan menjadi laporan dari penelitian ini.

\section{HASIL DAN PEMBAHASAN}

\section{Keadaan di Daerah Tertinggal}

Keadaan di daerah tertinggal sangat jauh dengan daerah yang maju, keadaan tersebut disebabkan oleh berbagai kondisi. Akses jalan untuk mencapai daerah tertinggal merupakan salah satu penyebab kurang adanya perhatian kepada daerah tertinggal.

Keadaan akses yang susah tersebut juga menjadi penyebab kurang perhatiannya pemerintah terhadap daerah tertinggal, karena hal tersebut penyediaan dan kebutuhan yang berhubungan dengan perkembangan daerah tertinggal terhambat. Tidak hanya itu, adanya sentralisasi terhadap sekolah yang notabene maju di daerah non pedesaan dan desentralisasi yang kurang efektif menjadi penyebab tidak meratanya pendidikan di Indonesia.

Pendidikan yang tidak merata tersebut akan menghambat terhadap pembangunan dan kualitas pendidikan, sehingga masalah pemerataan pendidikan menjadi hal krusial di antara masalahmasalah pendidikan yang ada di Indonesia.

Di antara daerah yang menjadi pusat penelitian ini adalah siswa di Sekolah Dasar (SD) yang berada di daerah Kabupaten Lebak, yang awalnya hanya sepuluh sekolah di Kecamatan Sobang, kemudian setelah berjalan waktu ditambah dengan empat kecamatan yaitu Cilenten, Bojong Manik, Cigemblong, dan Lebak Gedong. Penetapan daerah tersebut sebagaimana yang telah dicatat oleh Kemdikbud, salah satu dari daftar daerah tertinggal - daerah 3T- yaitu kabupaten Lebak.

Keadaan pendidikan daerah tersebut bisa dilihat dari masih banyaknya fasilitas pendidikan kurang layak pakai. Selain itu, kondisi siswa yang masih jauh dari harapan lingkungan pendidikan menjadi indikator tambahan, contohnya siswa kelas 6 SD belum bisa baca.

Dengan melihat fakta tersebut, membangun daerah tertinggal dalam hal pendidikan akan mendapat masalah besar. Oleh sebab itu diperlukan gagasan, ide, dan aktivitas berupa komunitas untuk mencapai tujuan dalam pembangunan pendidikan di daerah tertinggal. Walaupun konsekuensinya akan terdapat masalah baru berupa bagaimana cara menjalankan komunitas agar berjalan efektif, dengan demikian perlu adanya perhatian lebih terhadap instrumen komunitas itu - demi keberlangsungan pembangunan pendidikan di daerah tertinggal.

\section{Sobat Mengajar: Esensi Hingga Eksistensi [2]}

Sobat mengajar adalah perkumpulan atau komunitas yang bergerak pada ranah sosial pendidikan, berusaha menyadarkan mahasiswa agar sadar akan pendidikan terutama di daerah terpencil. Sasaran komunitas ini adalah keadaan daerah pelosok, maka tidak secara langsung sobat mengajar ini membantu meringankan beban pemerintah dalam hal pendidikan, terutama dalam masalah pemerataan pendidikan, baik dalam sektor fasilitas, pendidik, dan kualitas. Kurang meratanya pendidikan di Indonesia, sampai sekarang masih menjadi problem dan musuh terbesar bagi pendidikan Indonesia, susahnya akses ke daerah tertinggal masih menjadi salah satu faktor utamanya.

Komunitas ini dibentuk pada tanggal 24 Februari 2018 oleh sekelompok mahasiswa yang memang memiliki perhatian besar terhadap kondisi pendidikan di Indonesia, terutama di daerah tertinggal. Terbentuknya sobat mengajar ini merupakan usulan dari kepala UPTD (Unit 
Pelaksana Teknis Daerah) yaitu bapak Emang Suherman kepada Mus'ad Al-Habib yang merupakan relawan dari gerakan ayo mengajar, program tersebut dikhususkan untuk mahasiswa Fakultas Ilmu Tarbiyah dan Keguruan (FITK). Setelah mendapatkan rekomendasi dan amanat dari kepala UPTD, kemudian ia mengumpulkan 35 orang untuk merumuskan nama, program, dan langkah apa yang tepat sebagaimana rekomendasi dari kepala UPTD, kemudian lahirlah nama sobat mengajar.

Dengan melihat awal pembentukan dan perjalanan lahirnya sobat mengajar ini, ada beberapa hal yang krusial: pertama, sobat mengajar merupakan komunitas yang berasal dari orang-orang yang perhatiannya terhadap pendidikan sangat tinggi. Kedua, komunitas ini adalah komunitas yang bergerak dalam sosial pendidikan yang tidak hanya mahasiswa UIN Jakarta apalagi mahasiswa FITK, tetapi dikhususkan untuk mahasiswa yang berada di daerah Jabodetabek, dan ini menjadi pembeda dengan gerakan ayo mengajar yang merupakan program dari FITK. Ketiga, gerakan komunitas ini memusatkan aktivitasnya di daerah tertinggal khususkan di Provinsi Banten tepatnya di kecamatan Sobang, kabupaten Lebak.

Dari awal perumusannya, sobat mengajar terus berusaha menjaring mahasiswa yang benar-benar mempunyai perhatian terhadap keadaan pendidikan di Indonesia. Hal demikian tidak hanya menumbuhkan dan menjaring saja, sobat mengajar merupakan wadah untuk mahasiswa merealisasikan tridarma perguruan tinggi yaitu pendidikan dan pengajaran, penelitian dan pengembangan, dan pengabdian kepada masyarakat. Melihat tridarma tersebut, komunitas ini dengan umur kurang lebih dua tahun baru menjalankan tridarma yang pertama yaitu pendidikan dan pengajaran.

Dalam menjalankan program-programnya, sobat mengajar memberikan kualifikasi khusus untuk mahasiswa yang memang benar-benar ingin menjadi relawan di sobat mengajar, di antara kualifikasinya adalah sebagai berikut: pertama, mahasiswa aktif seJabodetabek. Pada awalnya, kualifikasi ini sangat umum, artinya, tidak mengenal semester, tidak mengenal jenjang $\mathrm{S} 1$ atau $\mathrm{S} 2$, yang terpenting ia masih dalam status mahasiswa. Kemudian, pada perkembangannya dipersempit dengan adanya batasan semester yakni yang bisa mengikuti adalah mahasiswa semester 2 sampai 8. Kedua, memiliki jiwa kepemimpinan. Ketiga, memiliki minat, motivasi, dan semangat untuk mengajar dan mengabdi di daerah terpencil. Keempat, siap ditempatkan selama tiga minggu di kecamatan Sobang, Kabupaten Lebak, Provinsi Banten. Penempatan di daerah Sobang ini sesuai dengan rekomendasi dari kepala UPTD, tetapi setelah beberapa gelombang komunitas ini memberikan kontribusi lebih, tidak hanya di kecamatan Sobang, ada beberapa kecamatan yang menjadi sasaran yakni kecamatan Cilinten, Bojong Manik, Cigemblong, dan Lebak Gedong. Kelima, sanggup mengikuti tahapan seleksi selama tiga tahapan. Pada tahapan pertama yaitu seleksi berkas, termasuk ada esai, CV, dan alasan kenapa masuk sobat mengajar; pada tahap kedua dilakukan wawancara; dan yang terakhir yaitu pembekalan. Setelah melewati tiga tahapan dan memenuhi kualifikasi dari sobat mengajar, calon relawan itu sudah menjadi bagian atau anggota dari sobat mengajar. Adapun jumlah anggotanya - relawan- sampai sekarang yaitu 120 orang, jumlah ini kemungkinan besar bertambah dengan antusias mahasiswa yang mengikuti di tahun ini. Dengan demikian, ada kurang lebih 120 relawan yang akan diberangkatkan ke lima kecamatan yaitu Sobang, Cilenten, Bojong Manik, Cigemblong, dan Lebak Gedong.

Kegiatan atau disebut dengan program sobat mengajar sebagaimana cita-cita awal dibentuknya komunitas ini tentunya akan berorientasi pada perbaikan kualitas pendidikan di daerah tersebut, di antaranya masih banyak siswa SD kelas 6 yang belum mahir dalam membaca, atas dasar itu langkah awal untuk menunjang siswa agar bisa membaca dan lebih giat dalam membaca dibentuklah taman baca. Program tersebut merupakan program wajib yang diterapkan setiap tahun, hingga saat ini. Dalam membangun taman baca ini, sobat mengajar merevitalisasi peran masyarakat dalam hal pendidikan dan tujuannya yaitu agar ada rasa memiliki sehingga taman baca yang sudah dibentuk dapat dimanfaatkan dengan jangka waktu yang panjang.

Dalam penguatan sosial dan kesejahteraan siswa di daerah tersebut, sobat mengajar membuat program yang tujuannya untuk kenyamanan belajar siswa tersebut. Program tersebut diberi nama dengan 1000 botol, program tersebut berangkat dari rasa empati para relawan melihat para siswa setiap berangkat ke sekolah mereka membawa air yang memakai bekas botol kecap. Atas dasar itu, para relawan mengumpulkan botol yang layak dipakai oleh siswa. Dengan adanya program tersebut secara tidak langsung mengedukasi siswa untuk peka sosial dan peduli terhadap sesama, dengan demikian relawan tersebut mengajarkan dalam hal afektif. 
Di antara gerakan dalam hal sosial, selain adanya program 1000 botol minum, komunitas ini membuat program 1000 kaos kaki yang akan diberikan kepada para siswa di daerah tersebut. Motif diadakannya program ini tidak jauh berbeda dengan program 1000 botol, tetapi pada program 1000 kaos kaki ini akan berimplikasi pada kegiatan dan kenyamanan pada saat belajar, sehingga akan berpengaruh juga pada hasil belajarnya. Kedua program 1000 botol dan kaos kaki tersebut termasuk dalam belajar sosial, yang tujuannya sebagaimana dikatakan oleh Muhibbin Syah, belajar sosial juga bertujuan untuk mengatur dorongan nafsu pribadi demi kepentingan bersama dan memberi peluang kepada orang lain atau kelompok lain untuk memenuhi kebutuhannya secara berimbang dan proporsional [3].

Selanjutnya, program yang masih bergerak dalam lingkaran sosial adalah cek kesehatan. Program tersebut merupakan program unggulan yang dibuat oleh komunitas ini dengan bertujuan untuk memberikan edukasi dan pemeliharaan terkait kesehatan. Hal demikian merupakan hal yang krusial karena pada hakikatnya kualitas kesehatan siswa akan memengaruhi terhadap proses belajarnya, dikatakan, "Akal yang sehat terdapat pada jiwa yang kuat", atas dasar itu sangat penting diadakan program tersebut. Dalam prosesnya, program ini bekerja sama dengan anak Politeknik Kesehatan Jakarta dan mereka juga mencari relawan yang dapat berkontribusi dalam program ini, di antara langkahnya yaitu: melakukan penyuluhan kesehatan, cek golongan darah, cek ideal berat badan, dan cek gizi. Untuk cek gizi ini tidak hanya siswa saja tetapi sasarannya meliputi orang tua siswa dengan harapan agar orang tua terus memperhatikan gizi anak selama proses belajar mengajar. Oleh sebab itu, faktor kesehatan dalam konteks ini akan mengubah pada kualitas pendidikan individu dan apabila berkelanjutan akan memengaruhi terhadap kualitas pendidikan di daerah tersebut.

Keterlibatan sobat mengajar dalam hal sosial pendidikan terlihat masif dengan adanya program desa berhijab. Landasan utama program itu dibentuk karena banyak perempuan di desa tersebut ketika beraktivitas sehari-hari tidak memakai hijab. Ada dua nilai yang dibentuk dengan program tersebut: pertama, norma dan kepatuhan beragama. Kedua, sosial dengan ditandai oleh kepedulian kepada perempuan tersebut. Dalam mencari dana dan jilbab, para relawan tersebut mengumpulkan donasi dari orang-orang yang memiliki jiwa sosial tinggi, kemudian hasil donasi itu didistribusikan kepada perempuan yang memang membutuhkan jilbab tersebut.

Selain siswa dan masyarakat yang menjadi sasaran dari program-program sobat mengajar, dalam kaitan degan pendidikan, guru menjadi aktor yang memang harus dibentuk kualitasnya karena guru yang berkualitas dan tidak berkualitas akan berpengaruh juga kepada status pendidikan tersebut, baik kualitasnya tinggi atau bahkan rendah. Dengan demikian, diperlukan satu langkah awal untuk membentuk guru yang berkualitas, di antaranya adalah mengadakan pelatihan guru. Pelatihan guru ini, pengisi sekaligus yang menjadi pematerinya yaitu dari dosen-dosen UMJ (Universitas Muhammadiyah Jakarta) dan FITK UIN Jakarta, mereka memberikan pelatihan RPP, pemberian modul, dan metode pengajaran yang bersifat praktis. Metode praktis yang dimaksud adalah sebuah cara yang tidak hanya teori-teori, tetapi lebih kepada praktik dan pengenalan satu materi yang praktis dan gampang dipahami. Berbeda dengan praktis, banyaknya teori terkadang akan membingungkan kepada siswa yang seharusnya pada usia tersebut siswa- membutuhkan pendidikan yang menyenangkan dan tidak menjadi beban. Melihat peran dan fungsinya guru sebagai aktor pendidikan tidak hanya berorientasi pada pembelajaran yang bersifat materi dan teori, tetapi guru menjadi media dan sarana motivasi belajar siswa. Oleh sebab itu, guru dituntut lebih inovatif dan kreatif dalam memberikan pembelajaran kepada siswa, di antara langkah yang konkret adalah dengan metode praktis.

Hubungannya dengan peran serta fungsi guru, menjadi motivator merupakan peran yang krusial. Walaupun dewasa ini peran siswa lebih dominan, berbeda dengan kurikulum sebelumnya KTSP tetapi peran guru sebagai motivator tidak akan tergantikan. Dan semua itu merupakan usaha yang terus dilakukan oleh sobat mengajar, tidak hanya menjadi guru sebagai pendidik tetapi guru harus sebagai motivator untuk meningkatkan motivasi belajar siswa. Berikut beberapa petunjuk umum untuk meningkatkan motivasi belajar siswa [4]: memperjelas tujuan yang ingin dicapai, membangkitkan minat siswa, ciptakan suasana yang menyenangkan dalam belajar, memberikan pujian yang wajar terhadap setiap keberhasilan siswa, berikan penilaian, berilah komentar terhadap hasil pekerjaan siswa, menciptakan persaingan dan kerja sama.

Dalam membentuk persaingan antara siswa, sobat mengajar memberikan fasilitas sebuah program 
yang sudah mewadahi siswa untuk bersaing secara sehat, program tersebut adalah Olimpiade Kecamatan Sobang (OKS). Olimpiade itu merupakan ajang unjuk kepandaian dari setiap siswa di sekolah-sekolah yang menjadi tempat relawan mengajar. Adapun sekolah yang menjadi tempat relawan sebagai berikut: SDN 2 Sobang, SDN 3 Hariang, SDN 4 Hariang, SDN 2 Hariang, SDN 2 Sinarjaya, SDN 1 Sinarjaya, SDN 1 Cirompang, SDN 1 Sukajaya, SDN 1 Sukaresmi, SDN 1 Sindanglaya. Dengan tujuan meningkatkan kualitas dan semangat bersaing di antara para siswa, program ini menjadi krusial karena selain tujuan tersebut, ada tujuan yang lain yaitu sebagai pembelajaran dalam bidang non akademik.

Di dalam persaingan dan kompetisi akan terbentuk motivasi diri, sebagaimana Sardiman menuturkan ada sebelas bentuk motivasi, yaitu: memberi angka, hadiah, saingan atau kompetisi, ego-involvement, memberi ulangan, mengetahui hasil, pujian, hukuman, hasrat untuk belajar, minat, tujuan yang diakui.

\section{Urgensi Komunitas Sosial Pendidikan}

Pentingnya pendidikan baik ruang lingkup pribadi, keluarga, masyarakat, dan bangsa tidak diragukan lagi, dengan pendidikan akan mengubah kehidupan baik dalam hal ekonomi, sosial, bahkan norma sekalipun. Tetapi yang menjadi problem sekarang adalah menurunnya kualitas pendidikan, terutama yang berada di daerah terpencil dikarenakan masalah pemerataan pendidikan. Tentunya dengan keadaan tersebut kehadiran komunitas sosial pendidikan mempunyai peranan lebih dalam mengurangi bahkan mengatasi problem tersebut. Sebagaimana yang dikatakan oleh Abdul Kadir, pemerataan pendidikan adalah persoalan yang terkait dengan sistem pelaksanaan sistem pendidikan yang dapat menyediakan kesempatan seluas-luasnya kepada warga negara untuk memperoleh pendidikan, sehingga pendidikan menjadi wahana bagi pembangunan sumber daya manusia dalam menunjang pembangunan suatu bangsa [5].

Melihat pokok masalah dalam pemerataan pendidikan tersebut, urgensi pertama hadirnya komunitas sosial pendidikan adalah berpartisipasi dalam pengembangan dan pembangunan bangsa. Dalam hal tersebut, dapat diakui bahwa pemerintah sebagai roda perjalanan terutama dalam pengembangan dan pembangunan bangsa masih mengalami kendala, khususnya untuk daerah terpencil. Komunitas sosial pendidikan hadir sebagai pembantu dan partisipan untuk hal tersebut, karena pada program-program yang dibentuk oleh komunitas tersebut akan berimplikasi pada sistem pendidikan dan memberikan kesempatan kepada masyarakat yang terkena dampak tidak meratanya pendidikan. Sebagai contoh di daerah terpencil itu masih banyak siswa yang belum bisa membaca, yang padahal kepandaian dalam membaca merupakan hak yang harus didapatkan oleh setiap warga negara. Prinsipnya, membaca merupakan salah satu sistem pendidikan yang harus dilaksanakan oleh pendidik sebagai pelaksana penyedia kesempatan yang seluas-luasnya bagi warga negara, sehingga pendidikan menjadi tempat bagi masyarakat untuk menunjang pembangunan suatu bangsa.

Di dalam pembangunan dan pengembangan bangsa tentunya harus disiapkan masyarakat yang benarbenar bisa berpartisipasi dalam misi besar itu, untuk bisa berpartisipasi masyarakat harus memiliki kualitas yang baik. Dengan pemerataan pendidikan masyarakat harusnya sudah siap untuk peran aktif dalam pembangunan bangsa. Komunitas ini secara tidak langsung menyiapkan masyarakat untuk berpartisipasi dan dapat dilihat dalam programprogram yang dijalankannya.

Setelah dilakukannya pemerataan pendidikan yang harus dilakukan adalah melakukan peningkatan dalam hal mutu pendidikan. Dengan demikian, komunitas ini tidak hanya membantu pemerintah dalam hal pemerataan pendidikan, tetapi membantu pemerintah meningkatkan mutu pendidikan. Dalam pembangunan bangsa tidak cukup dengan pemerataan pendidikan saja, akan tetapi harus memiliki sumber daya manusia yang berkualitas, di antaranya dapat dicapai dengan pendidikan yang berkualitas pula. Masalah pendidikan merupakan suatu kebutuhan yang paling mendasar dalam sebuah negara, karena keberhasilan pembangunan suatu bangsa ditentukan oleh keberadaan sumber daya manusia yang berkualitas, yang dihasilkan antara lain lewat pendidikan yang berkualitas [5]. Untuk mencapai mutu pendidikan (pendidikan yang berkualitas) komunitas sosial harus mempunyai ketersediaan ide atau gagasan untuk menjalankan proses dan pada akhirnya harus ada hasil yang sesuai dengan rencana awal. Ketersediaan ide atau gagasan dapat dilihat dari visi, misi dan tujuan komunitas tersebut; proses dapat dilihat dengan perjalanan dan bentuk program-program yang ia jalankan selama di lapangan; sedangkan hasil adalah pencapaian terakhir yang semula terdapat hanya dalam ide dan proses, bisa dilihat dalam kualitas, kinerja, dan produktivitas pasca kegiatan tersebut. 
Sebagai makhluk sosial, manusia mempunyai potensi diri untuk berinteraksi sosial, kontrol sosial, dan menyelesaikan konflik sosial. Dengan demikian, manusia yang hubungan sosialnya baik, peka terhadap lingkungan sekitar, dan peduli sesama mereka adalah makhluk yang mengoptimalkan potensinya sendiri. Dalam mengoptimalkan potensinya, manusia sebagai makhluk sosial secara tidak langsung akan mengalami proses humanisasi, yaitu proses untuk menjadikan manusia lebih manusiawi.

Umiarso dan Zamroni memaparkan lebih detail terkait humanisasi; misi utama manusia diciptakan ke dunia adalah humanisasi, sesuatu proses untuk menjadikan manusia lebih manusiawi. Sebagai sebuah proses, humanisasi melibatkan kesadaran kritis yang merupakan potensi kodrati manusia. Hal ini untuk membekali manusia dalam upaya memahami realitas dunia dan menciptakan struktur kebudayaan baru. Dengan kesadaran kritis, manusia hadir di dunia tidak hanya berada di dalamnya, tetapi ada bersamanya, keberadaannya mengisi ruang kosong dalam realitas kehidupan [6].

Sebagai bentuk dan upaya mengisi ruang kosong dalam realitas kehidupan, dalam konteks ini pendidikan, komunitas sosial pendidikan memiliki kedudukan yang sangat penting. Karena, esensi dari komunitas sosial pendidikan adalah mengisi ruang kosong yaitu kurang optimalnya pemerintah dalam mengakses pendidikan di daerah terpencil dan pengoptimalan potensi yang dimiliki oleh manusia relawan-.

Aktivitas komunitas sosial pendidikan tidak hanya mengisi ruang kosong dalam konteks ini pendidikan saja, tetapi ada hal yang lebih urgen yaitu menjadi kontrol sosial dan pengendalian sosial. Kontrol sosial adalah merupakan suatu mekanisme untuk mencegah penyimpangan sosial dan mengarahkan masyarakat untuk berperilaku dan bersikap sesuai norma dan nilai yang berlaku [7]. Kontrol sosial atau pengendalian sosial bertujuan untuk mengubah masyarakat yang mempunyai sifat atau perilaku yang menyimpang atau membangkang, dan tidak menaati norma-norma yang ada, baik norma yang berhubungan dengan sosial langsung ataupun norma yang secara tidak langsung berhubungan dengan sosial. Sebagai contoh di daerah Sobang masih banyak wanita muslimat yang belum berhijab/berkerudung di dalam menjalankan aktivitasnya di luar rumah, dengan demikian muslimat tersebut melanggar satu norma dan nilai yang berlaku di masyarakat tersebut, yaitu, norma agama. Atas dasar itu, sobat mengajar -sebagai komunitas sosial pendidikan- membuat satu program yang disebut dengan desa berhijab. Oleh karena itu, komunitas tersebut telah menjalankan kontrol sosial atau pengendalian sosial.

Secara luas kontrol sosial tidak hanya terjadi di masyarakat saja, tetapi kontrol sosial terjadi di mana pun, seperti: keluarga, sekolah, dan masyarakat [8]. Sudah jelas kontrol sosial konteksnya di sekolah dengan program yang mendorong perubahan pendidikan, seperti program taman baca dan pelatih guru merupakan bukti bahwa komunitas sosial pendidikan sebagai kontrol sosial. Pada hakikatnya, siswa dan guru yang tidak sesuai dengan harapan kelompok dan masyarakat itu termasuk dalam penyimpangan, contohnya, siswa kelas 6 SD masih belum mahir membaca. Wickman mengatakan, penyimpangan (deviance) perilaku yang melanggar standar perilaku atau harapan dari sebuah kelompok atau masyarakat [8].

Komunitas sosial pendidikan disebut juga dengan faktor lingkungan yang dapat memengaruhi berjalannya sebuah pendidikan. Faktor lingkungan yang oleh Ki Hajar Dewantara disebut dengan "Tri Pusat Pendidikan" yaitu tiga pusat lingkungan pendidikan. Kenapa komunitas tersebut masuk dalam tri-pusat pendidikan? Karena secara implisit masuk dalam tatanan dan termasuk dalam bagian masyarakat. Nazili Shalih Ahmad berpendapat yang dimaksud masyarakat adalah sekumpulan orang atau sekelompok manusia yang hidup bersama di suatu wilayah dengan tata cara berpikir dan bertindak yang relatif sama yang membuat warga masyarakat itu menyadari diri mereka sebagai suatu kelompok [9]. Implikasinya, semua unsur yang terdapat di dalam masyarakat mesti akan memengaruhi perkembangan anak siswa terutama dalam pendidikan, baik bernilai positif atau negatif. Dengan demikian, perlu adanya pemeliharaan yang komprehensif untuk komunitas tersebut agar terus bernilai positif dan memberikan dampak yang baik bagi lingkungan sekitar.

GBHN 1983 mengamanatkan terkait komunitas itu sosial pendidikan-, "Perkembangan wadah-wadah generasi muda seperti organisasi siswa intra sekolah (OSIS) dan organisasi mahasiswa dilingkungan perguruan tinggi, organisasi fungsional pemuda seperti antara lain KNPI, Pramuka, Karang Taruna, organisasi olahraga, dan lainnya perlu ditingkatkan secara terarah dan teratur" [9]. Atas dasar itu, komunitas seperti sobat mengajar harus terus dipelihara dan dikembangkan baik dalam hal 
kuantitas dan kualitasnya, agar terus berkontribusi di masyarakat, sekolah dan negara.

\section{Menjadi Umat Terbaik: Akhir dari Pembangunan Pendidikan}

Pendidikan terbaik merupakan cita-cita bagi setiap bangsa, berbagai macam pembangunan pendidikan terus ditingkatkan, di antaranya dengan memperbarui kurikulum, dana pendidikan diperbanyak, mutu guru ditingkatkan, dan sarana prasaran diperbaiki, walaupun masih belum maksimal, artinya masih ada usaha yang dilakukan oleh para pemegang kebijakan pendidikan.

Pembangunan pendidikan yang terus diusahakan akan terasa dan terlihat kalau hasil dari pembangunan itu terlihat, lalu apa hasil yang terbaik dari pembangunan pendidikan? Prestasi? Banyaknya aktor pendidikan?, semua yang disebutkan memang benar tetapi ada yang lebih tepat yaitu menjadi umat terbaik (khairu ummah), dan hasil ini merupakan keberhasilan yang paripurna.

Umat terbaik atau khairu ummah sebagaimana yang tercantum dalam Al-Quran Q.S Ali Imran: 110, "Adalah kamu sebaik-baik umat yang dikeluarkan buat manusia, menyuruh kepada yang makruf dan melarang dari yang mungkar serta beriman kepada Allah". Jaminan Allah subhanahu wa taala menjadikan kita sebagai umat yang terbaik tentunya tidak spontanitas, tetapi ada usaha kita sebagai makhluk, di antara usahanya yaitu membangun pendidikan yang ideal dan berkualitas.

Khairu ummah dalam pandangan K.H Irfan Hielmy adalah usahanya merekonstruksi hubungan antara keislaman dan keindonesiaan. Hal ini dilakukan agar umat memiliki pemahaman Islam yang Kaffah (utuh) yang mampu dipraktikkan dalam kehidupan sehari-hari. Oleh sebab itu, pandangan Khairu ummahnya dititikberatkan pada strategi-strategi pembangunan sumber daya manusia berkualitas [10]. Dengan demikian, pembangunan sumber daya manusia yang berkualitas sebagai penekanan pada khairu ummah harus sejalan dengan perwujudan atas pembangunan pendidikan.

Untuk mewujudkan khairu ummah tentunya diperlukan konsep dan rumusan yang jelas agar tercapai apa yang dicita-citakan, dalam hal ini AlGhazali menyebutnya dengan insān kamīl [10] yaitu menjadi manusia yang sempurna.
Untuk mencapai manusia sempurna tentunya ini tidak mudah karena kualifikasi yang sangat ketat yaitu memiliki kecerdasan spiritual yang berhubungan langsung dengan Tuhan dan kecerdasan sosial yang hubungannya dengan makhluk. Dua kualifikasi ini tidak akan tercapai apabila tidak memiliki sifat benar, dapat dipercaya, menyampaikan, tajam pikiran, cerdas, dan cerdik. Menurut K.H Irfan Hielmy indikator dari insān kamīl tersebut, yaitu: pertama, manusia yang kuat akidahnya. Kedua, manusia yang berakhlak mulia. Ketiga, manusia yang memiliki wawasan luas. Keempat, manusia yang memiliki visi tajam. Kelima, manusia yang bersikap bijaksana. Keenam, manusia yang penuh kelembutan [10]. Indikator tersebut apabila kita cermati akan sejalan dengan cita-cita pembangunan pendidikan, oleh sebab itu pembangunan pendidikan yang berhasil akan menghasilkan manusia sempurna.

Sama halnya dengan gagasan atau penyebutan oleh Al-Ghazali, menurut Kohnstamm dan Gunning tujuan akhir pendidikan itu ialah membentuk insan kamil atau manusia sempurna [9]. Dengan demikian tujuan akhir dari pembangunan pendidikan yaitu menjadikan manusia sebagai makhluk yang sempurna atau kata lain menjadi insan kamil sehingga akan mendapatkan predikat umat yang terbaik.

\section{KESIMPULAN}

Komunitas sosial pendidikan yang bergerak dalam hal sosial khususnya pendidikan memberikan dampak yang signifikan terhadap keadaan sosial masyarakat dan keadaan pendidikan di Indonesia khususnya di daerah terpencil. Sobat mengajar hadir dengan inovasi dan program-program yang mengarah pada pemerataan pendidikan dan pembangunan daerah terpencil. Dalam hal ini perlunya dukungan baik dalam hal materiel ataupun imateriel dengan tujuan pengoptimalan sobat mengajar lebih baik lagi. Tidak hanya membangun taman baca, tetapi harus dengan membangun daya saing agar pembangunan pendidikan daerah terpencil lebih baik lagi. Tidak cukup dengan siswa yang dibina, tetapi faktor lingkungan pendidikan tetap harus menjadi prioritas utama, tujuannya agar kesinambungan peradaban dan pembangunan pada tempat tersebut terus berkembang, hingga pada akhirnya akan menjadi khairu ummah (umat yang terbaik). 


\section{REFERENSI}

[1] Pusat Data dan Statistik Kemdikbud, Jumlah Ruang Kelas Menurut Kondisi Tiap Provinsi dan Jumlah Perpustakaan Menurut Kondisi Tiap Provinsi, 31 Desember 2018 http://statistik.data.kemdikbud.go.id/ [Diakses: 28 Desember 2019].

[2] Wawancara dengan saudara Kelvin Haiqal salah satu relawan sekaligus pencetus komunitas sobat mengajar, tentang sejarah, keberadaan dan program sobat mengajar, pada pukul 08:16 WIB tanggal 18 Desember 2019 di Ciputat Timur, Tangerang Selatan.

[3] M. Syah, Psikologi Pendidikan dengan Pendekatan Baru, Bandung: PT Remaja Rosdakarya, 2014.

[4] U. Saefullah, Psikologi Perkembangan dan Pendidikan, Bandung; CV Pustaka Setia, 2012.

[5] A. Kadir, Dasar-Dasar Pendidikan, Edisi Petama, Jakarta: Kencana Prenada Media Group, 2012.
[6] Umiarso and Zamroni, Pendidikan Pembebasan Dalam Perspektif Barat dan Timur, Cetakan Pertama, Yogyakarta: Ar-ruz Media, 2011.

[7] R. F. Riani, Kontrol Sosial atau Pengendalian Sosial, 29 Juli 2012 [online], https://www.academia.edu/8676046/KONTR OL SOSIAL atau PENGENDALIAN_SOS IAL [Diakses: 29 Desember 2019].

[8] W. Putri, Kontrol Sosial, 29 Oktober 2014, https://www.kompasiana.com/wahyuputri/54 f94cefa33311b77f8b4ae8/kontrol-sosial [Diakses: 29 Desember 2019].

[9] H. M. A. Sabri, Pengantar Ilmu Pendidikan, Cetakan Pertama, Jakarta: UIN Jakarta Press, 2005.

[10] A. L. Majdi, K.H Irfan Hielmy dan Interpretasi Khairu Ummah, Jurnal Sejarah Peradaban Islam, Vol. 1, No. 1, 2017. 